\title{
AVALIAÇÃO DA RESISTÊNCIA AO FOGO DE TUBULAÇÕES DE COMPOSTOS VINÍLICOS EMPREGADAS EM SISTEMAS PREDIAIS DE CHUVEIROS AUTOMÁTICOS PARA EXTINÇÃO DE INCÊNDIO
}

\author{
Carlos Roberto M. de Oliveira ${ }^{(1)}$; Orestes M. Gonçalves ${ }^{(2)}$ \\ (1) Escola Politécnica da Universidade de São Paulo, carlos.metzker@poli.usp.br \\ (2) Escola Politécnica da Universidade de São Paulo, orestes.goncalves@poli.usp.br
}

\begin{abstract}
RESUMO
Este trabalho estabelece critérios para avaliar a resistência ao fogo de tubulações fabricadas com compostos vinílicos, com diferentes teores de cloro, para os sistemas prediais de chuveiros automáticos, verificando o relacionamento entre os resultados obtidos nos ensaios realizados em trechos de tubulações pressurizados e submetidos a uma elevação de temperatura e os resultados observados nos ensaios realizados em tubulações em escala real exposta diretamente às chamas, simulando uma situação de incêndio. Assim, nos ensaios em trechos de tubulações ocorreu um aumento da resistência ao fogo proporcional ao aumento do teor de cloro dos compostos; nos ensaios em tubulações em escala real observou-se que corpos-de-prova com tubos vinílicos grau a partir de 64 (grau este relacionado ao teor de cloro) suportam as condições de exposição ao fogo; a relação entre os ensaios mostrou que tubulações fabricadas com um composto vinílico com resistência a partir de 110 segundos de exposição ao fogo, no ensaio em trechos de tubulações, suportam também as condições estabelecidas no ensaio em escala real. Isto indicou a possibilidade de se utilizar o ensaio em trechos de tubulações para avaliar, preliminarmente, a capacidade dos materiais em resistir ao fogo, antes de serem submetidos ao ensaio em escala real, pois este apresenta maiores custos envolvidos e maiores dificuldades na sua execução.
\end{abstract}

Palavras-chave: sistemas de chuveiros automáticos, incêndio, ensaios de materiais, resistência ao fogo

\section{INTRODUÇÃO}

A ocorrência de um incêndio causa tragédias irreparáveis, dentre elas, sem dúvida nenhuma, a principal é a perda de vidas humanas, que ocorrem geralmente de maneira violenta e trágica aos olhos da sociedade.

Frente à ameaça representada pelo incêndio e para reduzir seus efeitos devastadores faz-se necessário objetivar, para todo o tipo de edificação, a segurança contra o incêndio, possibilitando uma maior probabilidade de evitar perdas de vidas humanas e econômicas. Para isso vários aspectos devem ser levados em conta como: criação de regulamentações e normalizações; educação das pessoas em segurança contra incêndios; aplicação dos conceitos de sistema global de segurança contra incêndio nos projetos arquitetônico das edificações; maior uso e manutenção de sistemas de combate ao incêndio; fiscalização; práticas de planos de escape da edificação, formação de brigadas, pesquisas e estatísticas, entre outros.

Os sistemas de chuveiros automáticos já mostraram em diversos estudos a sua importância no combate ao incêndio nas edificações. Desta forma, em se tratando de proteção ativa por chuveiros automáticos em edificações, um projeto bem definido de combate ao incêndio e a utilização de materiais adequados devem ser estudados, avaliados e implementados de maneira a estabelecer condições mínimas de segurança da edificação. Atualmente, no Brasil, somente materiais metálicos (aço e cobre) são permitidos na fabricação de tubos e conexões para sistemas de chuveiros automáticos, mas como novos materiais, em especial plásticos, estão no escopo da revisão da Norma Brasileira NBR 10867, estes devem ser avaliados através de ensaios laboratoriais e programas de qualidade, para que possam ser utilizados e, assim, proporcionar novas alternativas de projetos.

Assim, o objetivo principal deste trabalho é estabelecer critério para avaliar a resistência ao fogo de tubulações fabricadas com compostos vinílicos, com diferentes teores de cloro, empregadas em sistemas prediais de chuveiros automáticos para extinção de incêndios, verificando o relacionamento entre os resultados obtidos em ensaios realizados em trechos de tubulações pressurizados e submetidos 
a uma elevação de temperatura e os resultados observados em ensaios realizados em tubulações em escala real expostas diretamente às chamas.

Vale ressaltar que, para todas as tubulações fabricadas com os materiais plásticos, os seguintes critérios são estabelecidos para o seu uso:

- Somente em sistemas de chuveiros automáticos de tubulação molhada;

- Ocupações de risco leve, ou seja, ocupações ou parte das ocupações onde a quantidade e/ou a combustibilidade do conteúdo (carga incêndio) é baixa tendendo a moderada;

- Onde os tubos e conexões são completamente separados por barreiras de proteção resistentes ao fogo (Ex: forros), ou seja, os tubos e conexões não devem estar expostos diretamente às chamas.

\section{EXPERIMENTAL}

A metodologia de pesquisa para avaliação do desempenho das tubulações fabricadas com os diferentes compostos vinílicos, com relação à capacidade de resistir às altas temperaturas (resistência ao fogo), é baseada em ensaios laboratoriais, de modo a contemplar e simular os fatores envolvidos na ocorrência de incêndios e, assim, permitir o fornecimento de dados suficientes para tal avaliação. Para isso, são adotados ensaios laboratoriais em trechos de tubulações, onde é avaliado o tempo de ruptura dos corpos-de-prova com relação elevação de temperatura do forno e de ensaios em tubulações em escala real, onde são avaliados vazamentos das tubulações durante e após a exposição direta à chama. A Figura 1 apresenta o fluxograma da metodologia de avaliação.

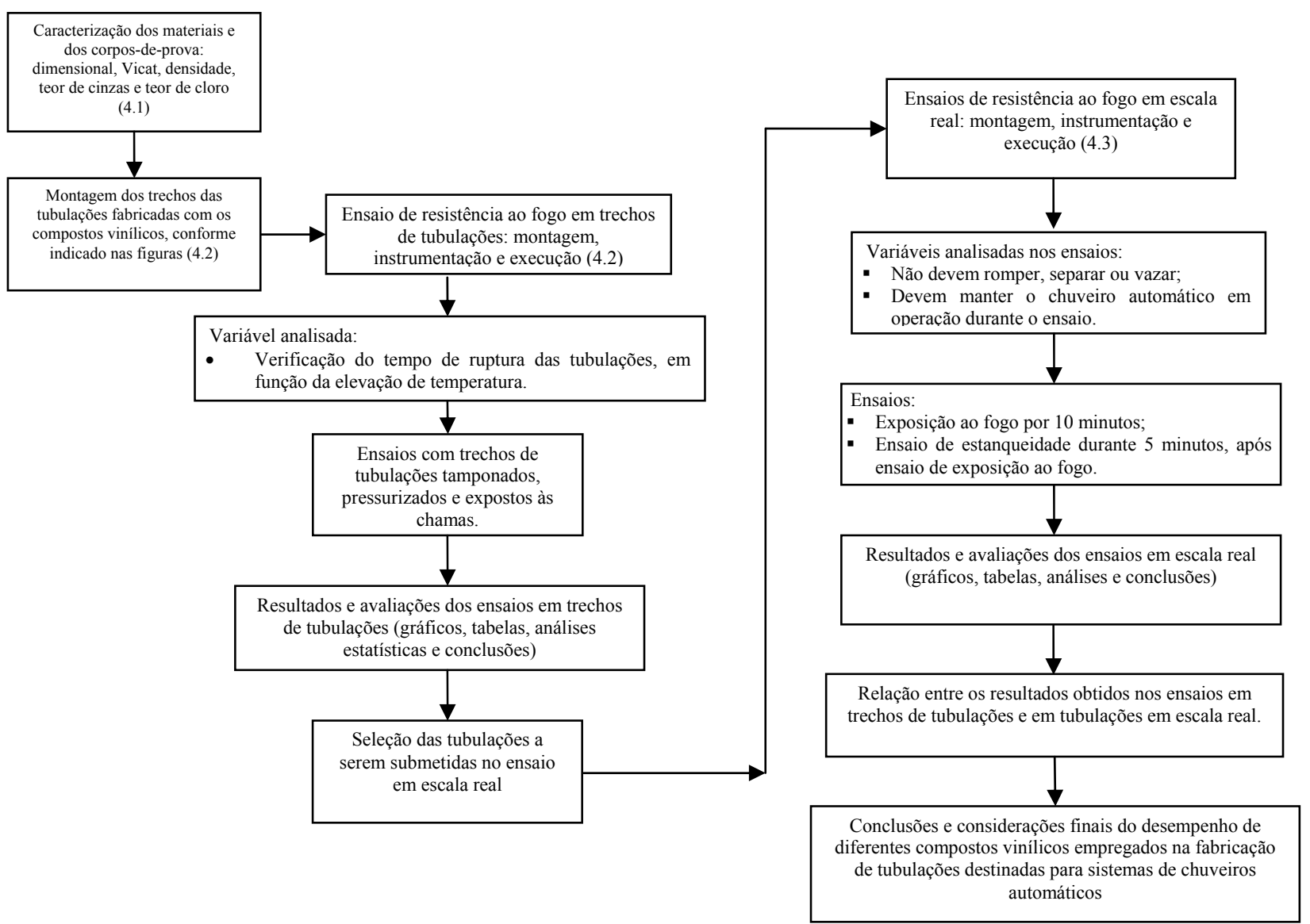

Figura 1 - Fluxograma da metodologia de avaliação da resistência ao fogo de tubulações fabricadas com compostos vinílicos para sistemas prediais de chuveiros automáticos 


\subsection{Caracterização dos materiais utilizados na fabricação dos corpos-de-prova}

Para caracterização dos materiais foram obtidos, junto aos fabricantes de resinas, compostos e tubulações, os valores de espessura de parede dos corpos-de-prova e diâmetro externo (dimensional), temperatura de amolecimento "Vicat", densidade, teor de cinzas e teor de cloro das composições.

Os ensaios dimensionais são para verificar a espessura de parede e o diâmetro externo de todos os corpos-de-prova, o ensaio de temperatura de amolecimento "Vicat" é para fornecer a idéia aproximada da máxima temperatura de utilização do material, a determinação do teor de cinzas objetiva verificar os minerais contidos no produto, a determinação da densidade objetiva verificar a massa por unidade volume dos materiais e o ensaio de teor de cloro, realizado por "Espectrometria de Fluorescência de Raios-X por Dispersão de Energia (ED-XFR)", objetiva através desta levantamento verificar a porcentagem de cloro, em massa, dos diferentes compostos utilizados na fabricação dos corpos-deprova e, em função disto, classificar os corpos-de-prova para os ensaios.

\subsection{Ensaios em trechos de tubulações}

Nesta etapa o comportamento de diferentes compostos vinílicos (em função das misturas e, consequentemente, dos teores de cloro) utilizados na fabricação de corpos-de-prova é avaliado através de ensaios em trechos de tubulações, onde corpos-de-prova são submetidos a uma elevação de temperatura padronizada através do equipamento descrito abaixo. Os corpos-de-prova submetidos nestes ensaios são identificados e classificados posteriormente, sendo isto realizado em função dos resultados obtidos no ensaio de caracterização do teor de cloro dos materiais.

A conformação dos corpos-de-prova para a execução do experimento é apresentada na Figura 15 e as etapas para a execução dos ensaios são descritas abaixo:

- Colocação (montagem) de cada corpo-de-prova (trecho de tubulação) no forno de ensaio, conforme apresentado na Figura 2;

- Instrumentação do forno de ensaio e corpo-de-prova, ou seja, colocação de sensores de temperatura (termopares);

- Pressurização do sistema;

- Exposição do corpo-de-prova a uma elevação padronizada de temperatura x tempo.

O ensaio é avaliado através do tempo de ruptura, em relação à elevação de temperatura, para todos os trechos de tubulações, ou seja, para todos os corpos-de-prova fabricados com os diferentes compostos vinílicos.

Após a realização de todos os ensaios e análise das variáveis, são selecionadas as tubulações para os ensaios de resistência ao fogo em escala real, o qual será descrito na subseção 4.3. do presente trabalho.

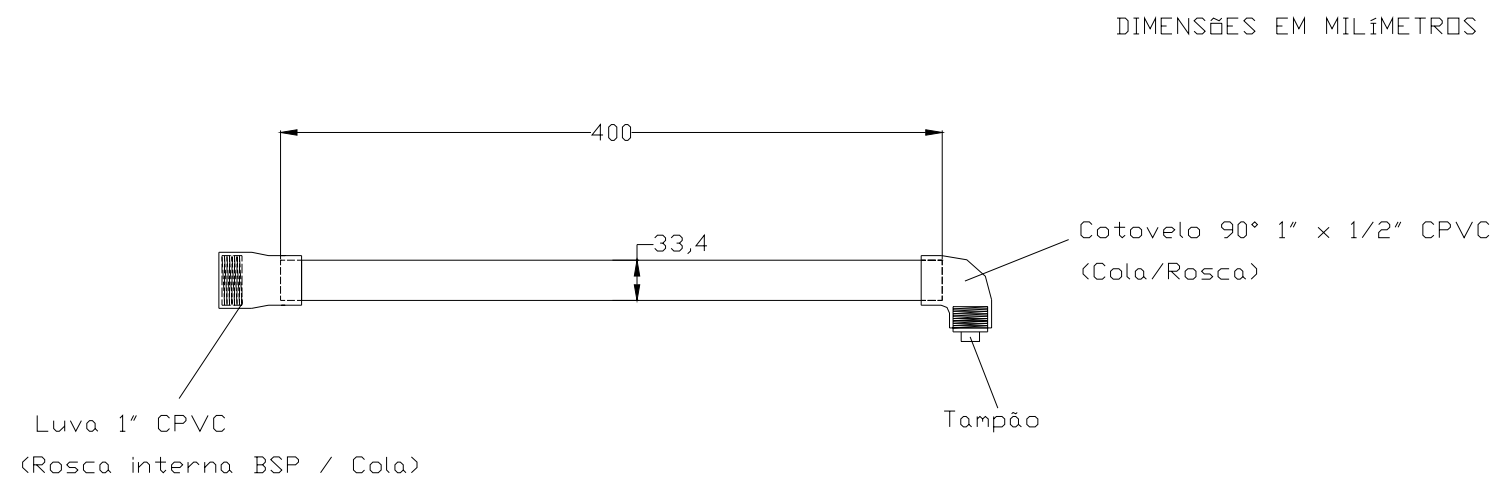

Figura 2 - Montagem dos corpos-de-prova

O equipamento de ensaio (forno) para esta etapa do trabalho é o mesmo descrito na norma NBR 6125:1992, a qual avalia o funcionamento de chuveiros automáticos, quando expostos a elevação de temperatura. Portanto, algumas modificações foram realizadas para a execução dos ensaios nas tubulações, sendo estas indicadas na Figura 3. O equipamento (forno) apresenta as dimensões de 
$520 \mathrm{~mm}$ de largura, $520 \mathrm{~mm}$ de altura e $520 \mathrm{~mm}$ de profundidade, tendo um queimador tipo prato alimentado por gás natural, rotâmetro para medição da vazão do gás e alimentação de água para a pressurização do sistema.

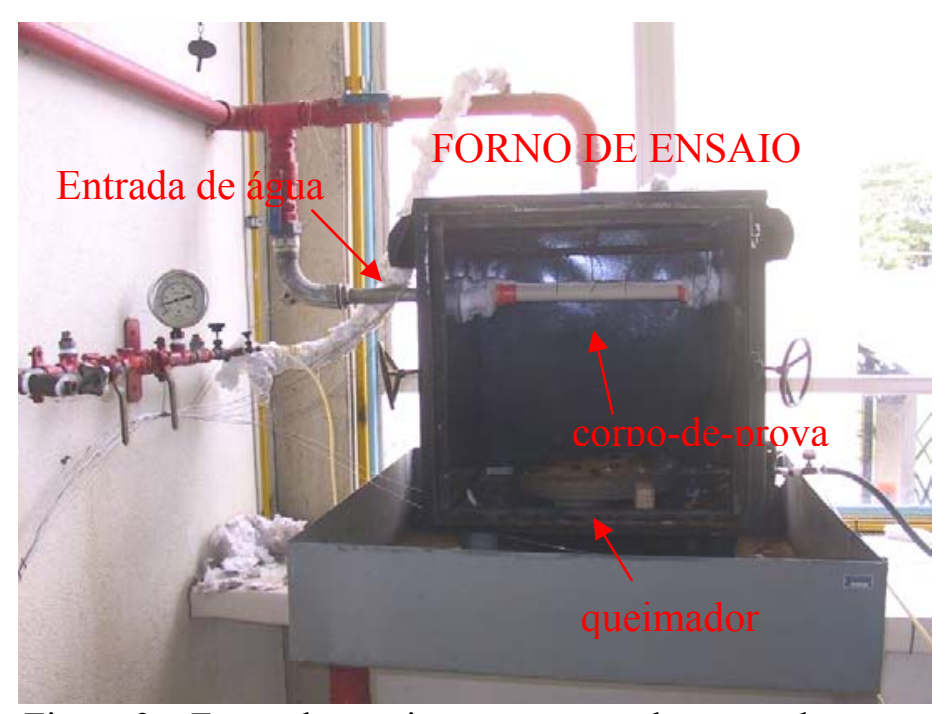

Figura 3 - Forno de ensaio e montagem do corpo-de-prova

Para as medições das temperaturas foi utilizado um registrador digital de 10 (dez) canais denominado "Data Logger Almemo 2290-8 V5", conectores e termopares tipo K de 1,5 mm de diâmetro. Já para a medição da pressão foi utilizado um manômetro analógico tipo "Bourdon" de escala 0 a $1000 \mathrm{KPa}\left(0\right.$ a $\left.10 \mathrm{kgf} / \mathrm{cm}^{2}\right)$ instalado na rede de abastecimento do sistema. Todos os dados obtidos foram, posteriormente, tratados em forma de planilhas (tabelas) e gráficos, através do software Microsoft Excel ${ }^{\circledR}$.

A curva de elevação temperatura interna em função do tempo do equipamento de ensaio (forno) está indicada na Figura 4, a qual apresenta o gráfico. Para todos os ensaios tal curva foi adotada.

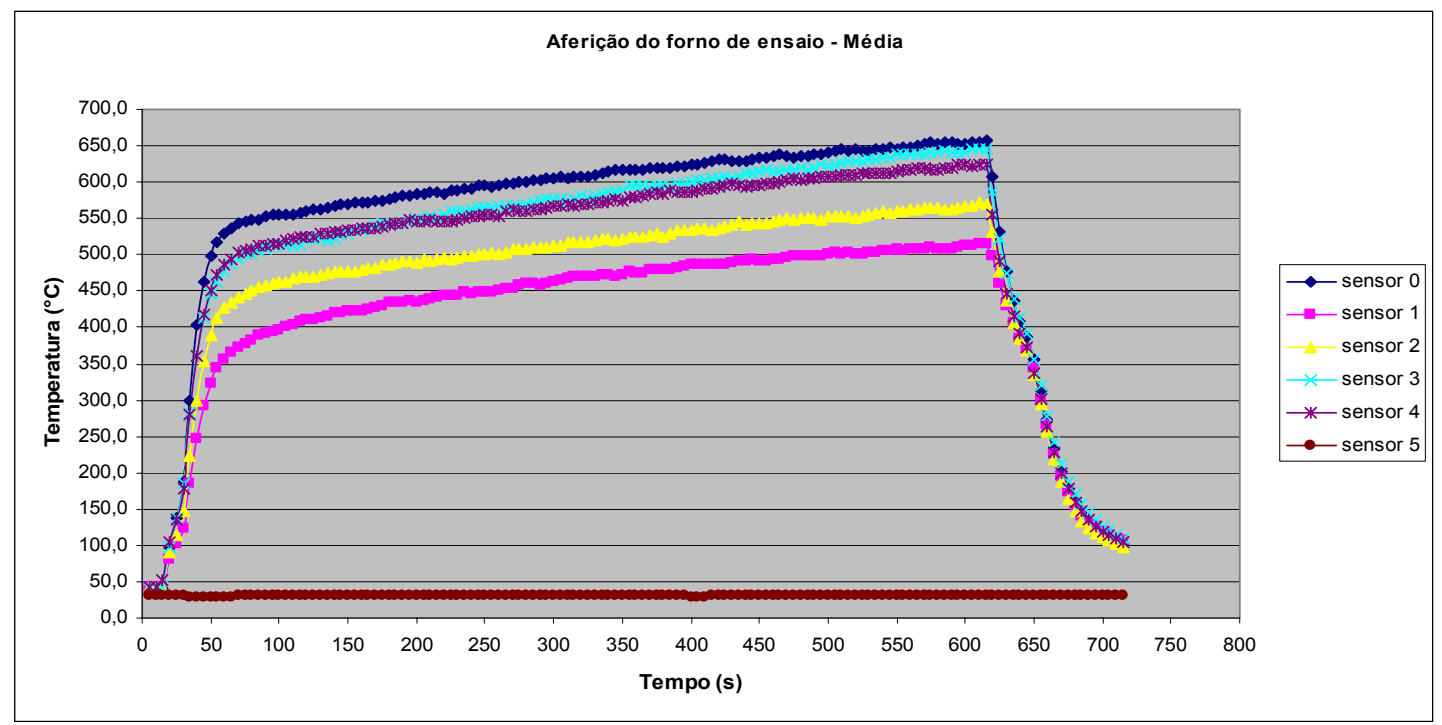

Figura 4 - Curva de elevação interna do forno de ensaio

Esta foi estabelecida através da disposição de termopares dentro do forno de ensaio, na posição de montagem dos trechos de tubulações, e com um ajuste da vazão do gás natural no queimador em, aproximadamente, $14 \mathrm{l} / \mathrm{min}$. Três medições da elevação da temperatura foram realizadas, sendo os valores coletados através do registrador. Cada medição teve duração de 10 (dez) minutos e os valores comparados, sendo observado que a resposta do forno de ensaio foi similar para todas as medições. 


\subsubsection{Ensaios em tubulações em escala real}

Após a seleção dos corpos-de-prova através dos resultados obtidos nos ensaios em trechos de tubulações, estes são submetidos aos ensaios em escala real, para a confirmação de sua resistência ao fogo.

O ensaio de resistência ao fogo consiste na montagem a $70 \mathrm{~mm}$ do teto da câmara de ensaios, com auxílio de suportes (abraçadeiras), de tubulações fabricadas com os compostos vinílicos, com 4600 $\mathrm{mm}$ de comprimento (distância esta estabelecida em função da máxima permitida pela norma de sistema, para edificações de risco leve), contendo um chuveiro automático com temperatura de funcionamento de $68^{\circ} \mathrm{C}$ em cada uma de suas extremidades, conforme indicado na Figura 5. As tubulações são expostas diretamente às chamas e as temperaturas são monitoradas com auxílio de quatro termopares, um em cada chuveiro automático (ao lado destes) e dois a, aproximadamente, $10 \mathrm{~mm}$ abaixo da conexão "Tê". Já as pressões são monitoradas no transcorrer de todo o ensaio, através do auxílio de um transdutor de pressão na entrada de abastecimento de água. Tanto os valores da pressão como os das temperaturas são recolhidos através de um personal computer (PC) comum com placa de aquisição de dados e software. Os resultados são, posteriormente, tratados em forma de planilhas (tabelas) e gráficos, através do software Microsoft Excel ${ }^{\circledR}$.

A tubulação é pressurizada hidrostaticamente a, aproximadamente, $800 \mathrm{kPa}$ e exposta a chamas produzidas pela queima de combustível (n-heptano), armazenado em uma bandeja com $0,46 \mathrm{~m}^{2}$ de área e 0,305 de altura, posicionada sobre o piso e no centro da câmara de ensaios (ver Figura 6). A condição de exposição ao fogo é mantida por 10 minutos e, após esse período a tubulação é tamponada e pressurizada hidrostaticamente a uma pressão de trabalho do sistema por cinco minutos. A tubulação é considerada adequada ao método se não romper, separar ou vazar e se manter o chuveiro automático em operação durante os ensaios.

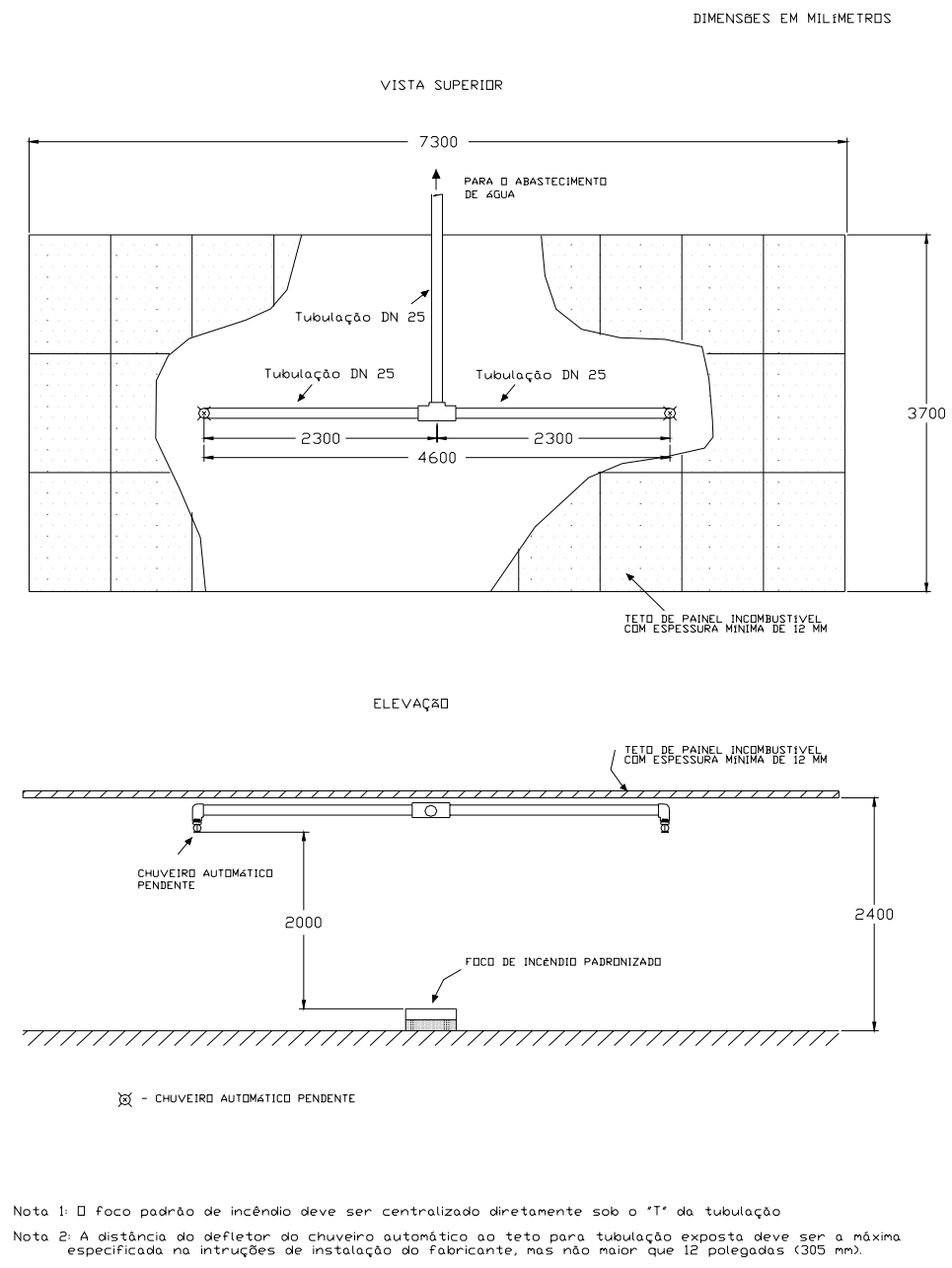

Figura 5 - Arranjo geral dos ensaios de resistência ao fogo em escala real 


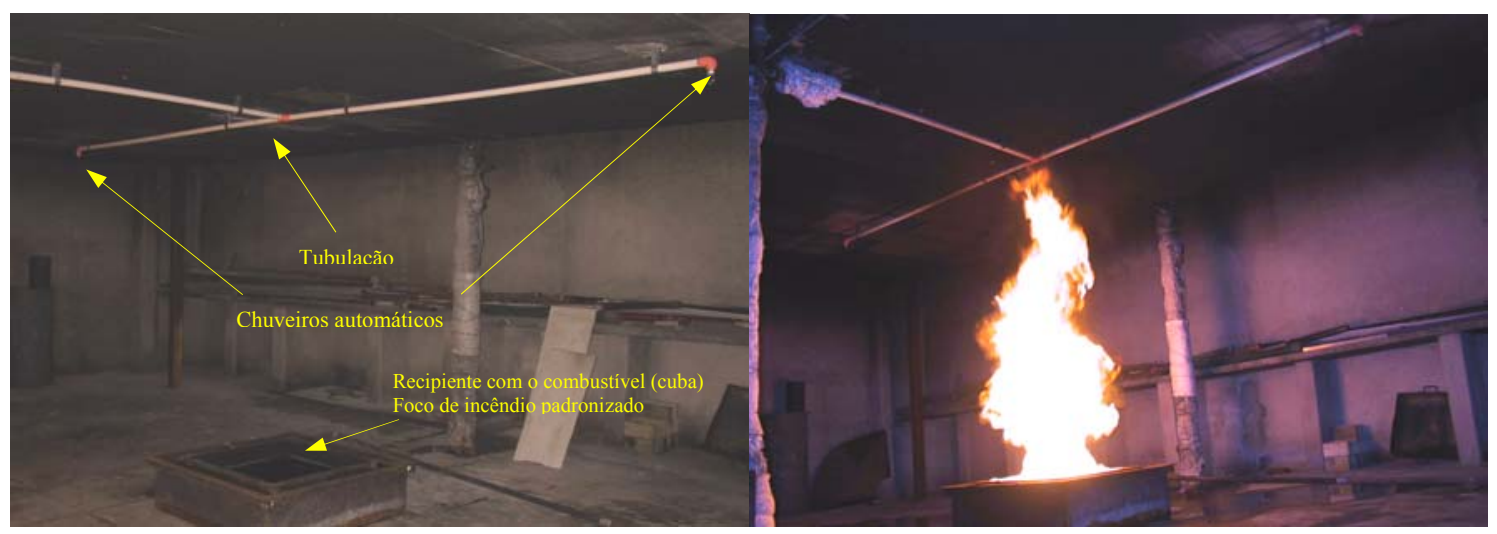

Figura 6: Montagem do corpo-de-prova e execução do ensaio de resistência ao fogo em escala real de tubulação destinada para sistema predial de proteção por chuveiros automáticos

\section{RESULTADOS E AVALIAÇÕES}

\subsection{Resultados da caracterização dos materiais e classificação dos corpos-de-prova utilizados na avaliação}

Através dos resultados obtidos no ensaio de teor de cloro dos materiais, os corpos-de-prova são classificados e identificados abaixo:

- Com o tubo vinílico grau 67 - tubo vinílico com teor de cloro da resina de $68,4 \%$ e teor de cloro do composto de $50,5 \%$;

- Com o tubo vinílico grau 66 - tubo vinílico com teor de cloro da resina de $66,9 \%$ e teor de cloro do composto de $49,4 \%$;

- Com o tubo vinílico grau 64 - tubo vinílico com teor de cloro da resina de $64,0 \%$ e teor de cloro do composto de $48,9 \%$;

- Com o tubo vinílico grau 62 - tubo vinílico com teor de cloro da resina de $61,5 \%$ e teor de cloro do composto de $47,4 \%$;

- Com o tubo vinílico grau 57 - tubo vinílico com teor de cloro da resina de 56,3\% e teor de cloro do composto de $45,6 \%$;

- Com o tubo vinílico grau 67BM - tubo vinílico importado com teor de cloro do composto de $52,5 \%$;

- Com o tubo vinílico grau 67BMT - tubo vinílico extrudado no Brasil com o composto importado, com teor de cloro do composto de 52,6\%.

Os valores percentuais de todos os corpos-de-prova correspondem aos resultados obtidos no ensaio de "Espectrometria de Fluorescência de Raios X". Os corpos-de-prova com tubo vinílico 67BM e 67BMT foram identificados através dos compostos por não serem conhecidas as resinas.

Para a presente avaliação, todas as conexões utilizadas são fabricadas com o mesmo material utilizado na fabricação dos tubos vinílicos Grau $67 \mathrm{BM}$, sendo, portanto, alterado a formulação dos compostos vinílicos dos tubos, isto em função, atualmente, da dificuldade em manipular o composto para injeção destas peças.

\subsection{Resultados dos ensaios em trechos de tubulações}

Os resultados dos primeiros ensaios indicaram alguns problemas no método de avaliação, já que alguns trechos estouravam na região superior e outros na região inferior. Isto se deu em função do calor por convecção do teto do equipamento (forno de ensaio). O problema foi resolvido com a colocação, para todos os corpos-de-prova, de uma camada de material isolante sobre a superfície superior. Portanto, as tubulações foram forçadas a romper na região de contato com a chama do queimador. Também, para alguns ensaios, a elevação interna do equipamento apresentou problema (problema com o queimador), não sendo computados para as análises. 
A Tabela 1 apresenta os resultados da avaliação da resistência ao fogo de tubulações fabricadas com compostos vinílicos apresentando diferentes teores de cloro, quando ensaiadas conforme o procedimento dos ensaios descrito no item 3.2 deste trabalho.

Tabela 1: Resultados dos ensaios em trechos de tubulações

\begin{tabular}{|l|c|c|c|c|c|c|c|c|c|c|}
\hline \multirow{2}{*}{ Identificação dos corpos-de-prova } & \multicolumn{9}{|c|}{ Tempo de resistência ao fogo (s) } \\
\cline { 2 - 12 } & $\mathbf{1}$ & $\mathbf{2}$ & $\mathbf{3}$ & $\mathbf{4}$ & $\mathbf{5}$ & $\mathbf{6}$ & $\mathbf{7}$ & $\mathbf{n}$ & Média & $\begin{array}{c}\text { Desvio } \\
\text { padrão }\end{array}$ \\
\hline Com tubo composto vinílico grau 57 & 55 & 60 & 45 & 60 & 55 & 55 & $\mathrm{x}$ & 6 & 55 & 5 \\
\hline Com tubo composto vinílico grau 62 & 65 & 80 & 75 & 70 & 70 & 75 & $\mathrm{x}$ & 6 & 73 & 5 \\
\hline Com tubo composto vinílico grau 64 & 110 & 110 & 115 & 125 & 110 & 90 & $\mathrm{x}$ & 6 & 110 & 11 \\
\hline Com tubo composto vinílico grau 66 & 170 & 270 & 160 & 145 & 200 & $\mathrm{x}$ & $\mathrm{x}$ & 5 & 189 & 50 \\
\hline Com tubo composto vinílico grau 67 & 145 & 220 & 205 & 185 & 155 & 150 & 165 & 7 & 175 & 29 \\
\hline Com tubo composto vinílico grau 67 BMT & 185 & 210 & 345 & 200 & 305 & 250 & 200 & 7 & 242 & 61 \\
\hline Com tubo composto vinílico grau 67 BM & 235 & 315 & 265 & 335 & 230 & $\mathrm{x}$ & $\mathrm{x}$ & 5 & 276 & 42 \\
\hline
\end{tabular}

Notas:

- Os números de 1 a 7 correspondem à seqüência das amostras (trechos de tubulações) ensaiadas;

- As cédulas marcadas com " $x$ " indica que o ensaio não foi realizado, pelo fato dos resultados serem suficientes para análise;

- As cédulas preenchidas em amarelo e sem números indica que o ensaio apresentou problema na elevação interna da temperatura (problema com o queimador), não sendo computados para as análises.

A Tabela 2 e a Figura 7 indicam, como exemplo, os resultados dos ensaios (média) dos corpos-deprova (trechos de tubulações) com o tubo vinílico Grau 64, com relação às temperaturas em função do tempo. As posições dos sensores números de 0 a 9 estão indicados na Figura 21. A queda nos valores das temperaturas obtidas pelos sensores indica o rompimento dos trechos de tubulações.

Tabela 2: Temperatura em função tempo dos ensaios em trechos de tubulações (corpos-de-prova) com tubo vinílico Grau 64

\begin{tabular}{|c|c|c|c|c|c|c|c|c|c|c|}
\hline \multirow{2}{*}{$\begin{array}{c}\text { Tempo } \\
(\mathbf{s})\end{array}$} & \multicolumn{9}{|c|}{ Temperaturas $\left({ }^{\circ} \mathbf{C}\right)$} \\
\hline & Sensor 0 & Sensor 1 & Sensor 2 & Sensor 3 & Sensor 4 & Sensor 5 & Sensor 6 & Sensor 7 & Sensor 8 & Sensor 9 \\
\hline 0 & 28,1 & 31,1 & 31,0 & 31,7 & 30,7 & 30,1 & 28,1 & 30,9 & 30,9 & 32,9 \\
\hline 5 & 28,1 & 31,4 & 32,1 & 32,8 & 36,8 & 33,0 & 28,1 & 38,5 & 47,4 & 47,8 \\
\hline 10 & 28,1 & 76,1 & 77,4 & 105,2 & 144,6 & 113,0 & 28,1 & 108,6 & 130,0 & 112,0 \\
\hline 15 & 28,1 & 169,8 & 174,3 & 222,5 & 282,8 & 244,3 & 28,2 & 214,5 & 241,0 & 197,5 \\
\hline 20 & 28,1 & 264,5 & 281,3 & 321,6 & 374,1 & 363,5 & 28,6 & 291,5 & 327,6 & 251,4 \\
\hline 25 & 28,1 & 307,8 & 338,7 & 365,1 & 408,7 & 426,0 & 30,1 & 334,8 & 382,9 & 286,0 \\
\hline 30 & 28,3 & 329,7 & 368,8 & 385,7 & 423,5 & 454,7 & 31,9 & 364,0 & 414,7 & 309,3 \\
\hline 35 & 28,5 & 344,0 & 388,0 & 401,0 & 434,1 & 474,1 & 33,4 & 384,3 & 437,0 & 328,2 \\
\hline 40 & 28,9 & 357,4 & 401,3 & 412,0 & 440,8 & 484,5 & 34,5 & 400,7 & 452,1 & 343,2 \\
\hline 45 & 29,5 & 367,6 & 412,6 & 421,9 & 448,5 & 493,6 & 35,1 & 412,0 & 462,3 & 355,5 \\
\hline 50 & 30,2 & 377,0 & 420,9 & 429,2 & 453,2 & 500,3 & 35,8 & 420,8 & 468,8 & 364,2 \\
\hline 55 & 30,8 & 384,3 & 425,8 & 435,8 & 457,8 & 502,8 & 36,6 & 428,5 & 472,7 & 371,2 \\
\hline 60 & 31,5 & 392,6 & 431,3 & 442,8 & 464,7 & 508,1 & 37,5 & 434,5 & 477,3 & 377,9 \\
\hline 65 & 32,2 & 395,8 & 435,4 & 448,4 & 467,9 & 510,6 & 38,3 & 437,8 & 483,2 & 382,5 \\
\hline 70 & 33,0 & 399,7 & 438,1 & 450,4 & 468,2 & 512,5 & 39,0 & 443,7 & 485,6 & 387,0 \\
\hline 75 & 33,6 & 406,6 & 440,9 & 455,9 & 474,6 & 511,1 & 39,7 & 444,2 & 483,4 & 391,1 \\
\hline 80 & 34,0 & 411,7 & 443,8 & 457,2 & 477,6 & 511,4 & 40,4 & 443,2 & 480,4 & 395,0 \\
\hline 85 & 34,4 & 415,7 & 447,6 & 458,0 & 481,1 & 511,9 & 41,2 & 442,8 & 479,9 & 397,8 \\
\hline 90 & 34,9 & 421,2 & 452,2 & 461,9 & 485,1 & 512,0 & 41,9 & 444,7 & 478,6 & 400,9 \\
\hline 95 & 34,2 & 423,2 & 447,1 & 456,6 & 466,4 & 496,2 & 39,7 & 427,9 & 456,3 & 386,6 \\
\hline 100 & 35,1 & 403,7 & 431,3 & 438,2 & 452,1 & 482,9 & 41,8 & 418,3 & 446,4 & 381,7 \\
\hline 105 & 36,8 & 400,8 & 426,8 & 432,0 & 450,4 & 476,7 & 44,1 & 413,7 & 440,1 & 378,8 \\
\hline 110 & 36,8 & 397,9 & 423,0 & 431,4 & 445,8 & 445,7 & 43,5 & 401,3 & 399,2 & 355,9 \\
\hline 115 & 32,6 & 361,3 & 320,6 & 381,7 & 371,6 & 362,3 & 37,9 & 349,1 & 333,9 & 307,4 \\
\hline 120 & 34,2 & 308,6 & 264,5 & 309,7 & 292,4 & 286,4 & 37,9 & 288,3 & 265,6 & 259,8 \\
\hline & & & & & & & & & & \\
\hline
\end{tabular}


Todos os ensaios com os trechos de tubulações (corpos-de-prova) indicados na subseção 5.1 apresentaram basicamente o comportamento indicado na Tabela 4 e na Figura 25, no que diz respeito ao aumento e queda das temperaturas durante estes ensaios. A diferença consistiu, particularmente para cada corpo-de-prova, no tempo de queda das temperaturas (maior ou menor) durante o transcorrer de cada ensaio, o qual indica o tempo de ruptura.

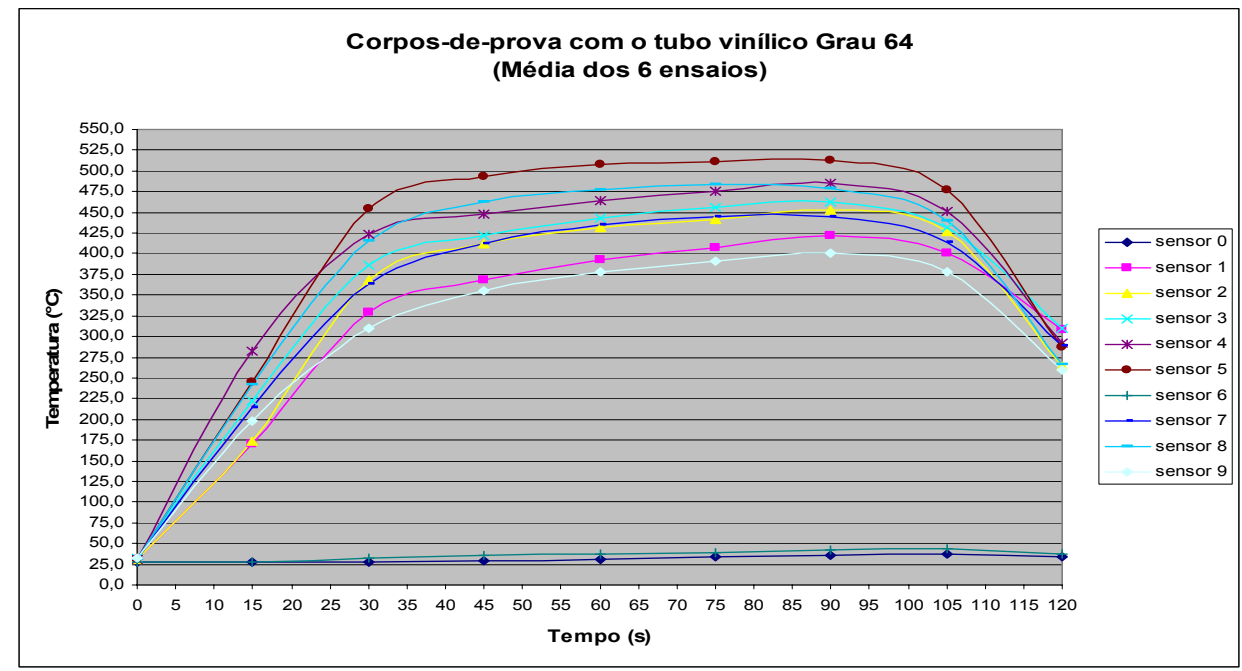

Figura 7: Gráfico das temperaturas durante os ensaios em trechos de tubulações com o tubo vinílico Grau 64

\subsection{Avaliação dos resultados obtidos nos ensaios em trechos de tubulações}

Para todos os trechos de tubulações ocorreu a ruptura na região central e inferior, ou seja, na região onde a chama do queimador do forno ficou em contato. Para os corpos-de-prova com o tubo vinílico Grau 57 e com o tubo vinílico 62 não ocorreu carbonização na região inferior. Já para os corpos-de-prova com o tubo vinílico 64, 66, 67, 67 BMT e 67 BM ocorreram carbonização na região inferior. As Figuras 8 e 9 apresentam tais modos de ruptura dos corpos-de-prova.

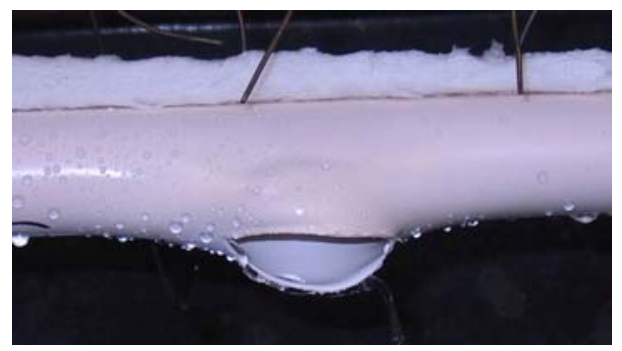

Figura 8: Foto do modo de ruptura dos corpos-de-prova sem carbonização inferior, após a execução do ensaio.

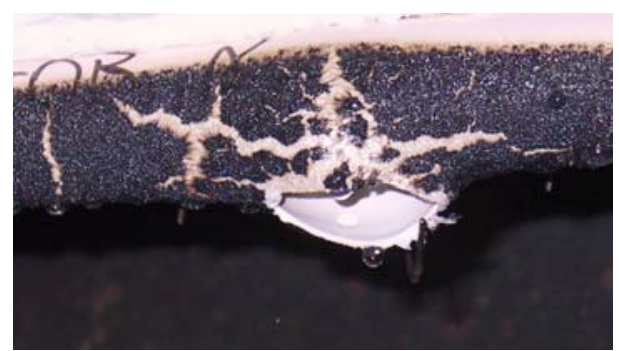

Figura 9: Foto do modo de ruptura dos corpos-de-prova com carbonização inferior, após a execução do ensaio. 
Os resultados obtidos nos ensaios em trechos de tubulações indicam que há uma influência significativa no aumento do tempo de ruptura da tubulação proporcional ao teor de cloro. Isto pode ser notado analisando os corpos-de-prova com os tubos vinílicos com grau variando entre 57 a 67 . Ainda, os corpos-de-prova com os tubos vinílicos grau 66 e 67 tiveram o mesmo comportamento, demonstrando que para esta variação na proporção de cloro o tempo de ruptura não foi alterado, assim como os corpos-de-prova identificados como grau 67 BM e 67 BMT, como era esperado, pois são fabricados com o mesmo composto. Isto mostra que a extrusão do tubo em locais diferentes (internacional e nacional) não alterou o comportamento ao fogo.

Os resultados dos ensaios em trechos de tubulações encontram-se avaliados dentro das técnicas usuais de Análise de Variância e de intervalos de confiança baseados na distribuição F de Snedecor, utilizando-se para tal o pacote estatístico disponível nos pacotes de software Minitab ${ }^{\circledR}$.A Análise de Variância é um método para identificar diferenças entre as médias populacionais, devidas a várias causas atuando simultaneamente sobre os elementos da população.

As análises estatísticas dos resultados com o software Minitab ${ }^{\circledR}$ permitem verificar que, as médias apresentam diferença significativa dentro um intervalo de confiança de $95 \%$ (nível de confiança $\alpha$ $=0,05=5 \%$ ). Este fato pode ser verificado através da comparação entre o resultado $\mathrm{F}$ obtido nos cálculos estatísticos com o F crítico. Os valores da análise de variância podem ser vistos na Tabela 3.

Tabela 3: Resultados da análise estatística dos ensaios trechos de tubulações. Valores obtidos através do software Minitab ${ }^{\circledR}$

\begin{tabular}{|l|c|c|c|c|c|}
\hline $\begin{array}{l}\text { Fonte de } \\
\text { variação }\end{array}$ & $\begin{array}{c}\text { Soma de quadrados } \\
\text { (SQ) }\end{array}$ & $\begin{array}{c}\text { Graus de } \\
\text { liberdade }\end{array}$ & $\begin{array}{c}\text { Quadrado } \\
\text { médio }\end{array}$ & $\mathbf{F}$ & \multirow{2}{*}{$\mathbf{F}_{\mathbf{6}, \mathbf{3 5}, \mathbf{5} \%}$} \\
\hline Entre amostras & 247320 & 6 & 41220 & \multirow{2}{*}{30,58} & \multirow{2}{*}{2,38} \\
\cline { 1 - 4 } Residual & 47170 & 35 & 1348 & & \\
\hline Total & 294490 & 41 & & & \\
\hline
\end{tabular}

A Figura 10 apresenta o gráfico boxplot ${ }^{24}$ do tempo médio de ruptura dos corpos-de-prova com os diversos compostos vinílicos, bem como as dispersões e as tendências dos valores. Como podem ser visto, os três primeiros conjuntos de corpos-de-prova (57, 62 e 64) apresentaram os valores individuais muito próximos. Já para os outros quatro conjuntos ocorreu uma dispersão maior nos resultados, representado pela maior amplitude nos diagramas das caixas. A dispersão dos resultados foi maior proporcionalmente ao tempo de execução dos ensaios, ou seja, em um ensaio onde o tempo de ruptura foi maior a variabilidade dos resultados teve maior ocorrência. Pelo gráfico apresentado na Figura 10 também é notada a linha ligando as médias de cada conjunto de corpos-de-prova, relativa ao aumento da resistência ao fogo proporcional ao aumento no teor de cloro.

Ainda, nota-se que não houve nenhum ponto discrepante no gráfico, que é um valor localizado distante de quase todos os outros pontos da distribuição, representado no gráfico, caso haja sua ocorrência, por meio de um asterisco na direção das linhas centrais dos diagramas de caixas, as quais são estabelecidas em função do limite inferior e superior de cada conjunto de resultados.

Portanto, através da execução dos ensaios nos diversos materiais aqui propostos e pela obtenção e análise estatística dos resultados, conclui-se através dos ensaios em trechos de tubulações, que a quantidade de cloro na formulação dos compostos empregados na fabricação dos corpos-de-prova aumenta o tempo de resistência ao fogo. Utilizando como referência o resultado do tempo médio de ruptura dos corpos-de-prova com o tubo vinílico grau 67BM para comparar o restante, por motivos já explicados anteriormente, conclui-se que os materiais com resultado próximo a este indicam a capacidade de resistir ao fogo no ensaio em escala real. Porém, não significa que os materiais utilizados na fabricação dos corpos-de-prova com tempo médio de ruptura inferior ao valor dos corpos-de-prova com o tubo vinílico grau 67BM sejam resultados negativos, sendo necessário avaliar o tempo de ruptura no ensaio em trechos de tubulações para relacionar com as condições do ensaio em escala real. 


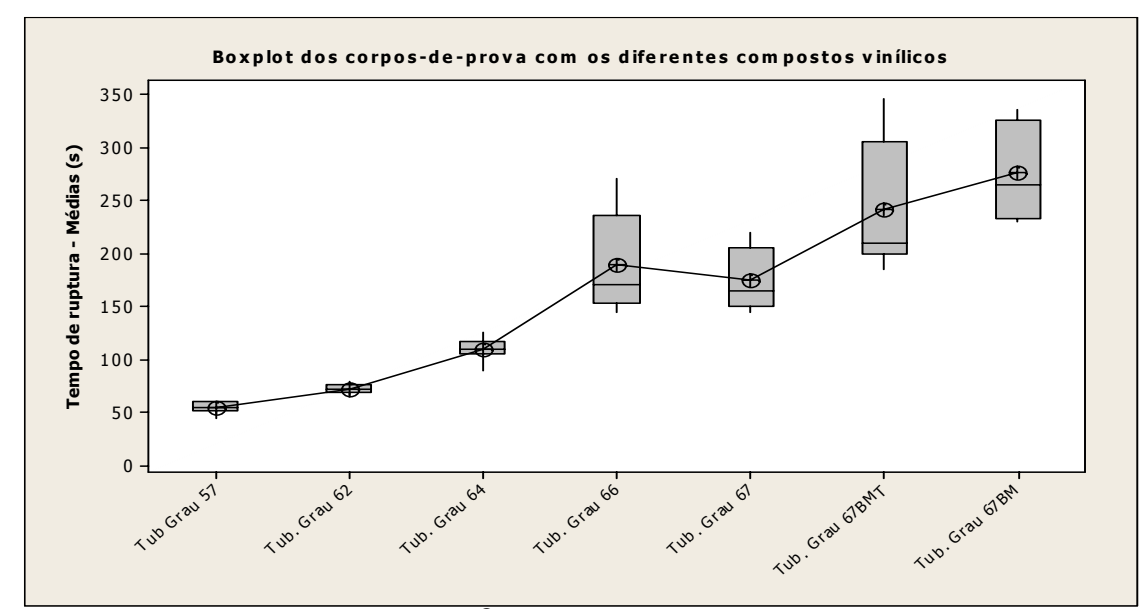

Figura 10: Gráfico boxplot software Minitab ${ }^{\circledR}$ para os ensaios em trechos de tubulações nos corpos-deprova com os diferentes compostos vinílicos

\subsection{Resultados dos ensaios em tubulações em escala real}

Os seguintes materiais utilizados na execução dos corpos-de-prova foram selecionados para os ensaios em escala real:

- Com o tubo composto vinílico grau 57 - tubo com composto vinílico apresentando teor de cloro de $45,6 \%$

- Com o tubo composto vinílico grau 64 - tubo com composto vinílico apresentando teor de cloro de $48,9 \%$

- Com o tubo composto vinílico grau 67 - tubo com composto vinílico apresentando teor de cloro de $50,5 \%$

- Com o tubo de composto vinílico grau 67BMT - tubo nacional (extrudado no Brasil com o composto importado) com composto vinílico apresentando teor de cloro de 52,6\%

Estes corpos-de-prova foram selecionados em função de estabelecer a possibilidade da relação entre os resultados obtidos nos ensaios em trechos de tubulações e os resultados nos ensaios em tubulações em escala real. Por esta razão, foram escolhidos materiais com resultados extremos nos ensaios em trechos de tubulações, intercalando dois entre eles, para, posteriormente, verificar qual tempo de ruptura obtido neste ensaio é suficiente para suportar as condições do ensaio em escala real.

Os resultados e desempenhos das tubulações, após serem submetidas às condições dos ensaios em escala real, são apresentados na Tabela 4, a qual indica se cada corpo-de-prova selecionado atendeu aos critérios do ensaio.

Tabela 4 - Resultados dos ensaios em tubulações escala real

\begin{tabular}{|l|c|c|c|}
\hline \multicolumn{3}{|c|}{ Resultados dos ensaios em escala real } \\
\hline Identificação dos corpos-de-prova & $\begin{array}{c}\text { A tubulação (corpo-de-prova) } \\
\text { estourou, separou ou vazou } \\
\text { durante os 10 minutos de ensaio } \\
\text { de exposição ao fogo? } \\
\text { (Sim ou Não) }\end{array}$ & $\begin{array}{c}\text { Manteve o chuveiro } \\
\text { automático em operação } \\
\text { durante o ensaio? } \\
\text { (Sim ou Não) }\end{array}$ & $\begin{array}{c}\text { A tubulação (corpo-de- } \\
\text { vazou durante os 5 min dos } \\
\text { ensaios de estanqueidade? } \\
\text { (Sim ou Não) }\end{array}$ \\
\hline Com tubo composto vinílico grau 57 & Sim & Não & Sim \\
\hline Com tubo composto vinílico grau 64- ensaio 1* & Não & Sim \\
\hline Com tubo composto vinílico grau 64- ensaio 2* & Não & Sim \\
\hline Com tubo composto vinílico grau 67 & Não & S** \\
\hline Com tubo composto vinílico grau 67 BMT & Não & Sim \\
\hline
\end{tabular}

Notas:

* Foram executados dois ensaios com o composto vinílico grau 64, pois no primeiro ocorreu uma grande defasagem na aberturas dos chuveiros.

** Não foi realizado o ensaio de pressão após o ensaio de exposição, devido à ruptura do corpo-de-prova.

*** Ocorreu um pequeno vazamento na junção entre conexão "Tê" e tubo, após exposição ao fogo. O tubo e a conexão não sofreram rupturas, sendo o vazamento na região da união. A pressão foi mantida após o ensaio de exposição. 
Para o corpo-de-prova com o tubo composto vinílico grau 57 ocorreu à ruptura aos 60 segundos após o início do ensaio, sendo esta na região do tubo próxima a conexão "Te" e devido a isto o ensaio foi encerrado. Para o corpo-de-prova com o tubo composto vinílico grau 64 ocorreu uma grande defasagem na aberturas dos chuveiros, porém, em nenhum dos ensaios foi verificado vazamentos.

Devido à defasagem na abertura dos chuveiros automáticos, um segundo ensaio foi realizado para outro corpo-de-prova. Porém, após o ensaio de exposição ao fogo notou-se um pequeno vazamento na junção entre conexão "Tê" e o tubo. Os tubos e as conexões não sofreram rupturas, sendo o vazamento na região da união, devido uma montagem mal executada. A pressão foi mantida após o ensaio de exposição. Para o corpo-de-prova com o tubo composto vinílico grau 67 não foi verificado durante e após o ensaio de exposição ao fogo, vazamentos e rupturas que comprometessem a integridade do corpo-de-prova, o mesmo ocorrendo para o corpo-de-prova com o tubo composto vinílico grau 67 BMT.

A Tabela 5 e as Figuras 11 e 12 apresentam um exemplo de monitoramento e resultados do ensaio em escala real. Neste caso foram utilizados os resultados do ensaio com o corpo-de-prova com o tubo composto vinílico Grau 67. A Tabela 6 apresenta os valores de temperatura e pressão durante os primeiros 90 segundos de ensaio. As Figuras 11 e 12 apresentam, graficamente, o monitoramento da pressão e temperaturas, respectivamente, durante o transcorrer de todo o ensaio (10 minutos). A queda repentina nas temperaturas dos sensores 1 e 4 (próximos aos chuveiros automáticos) indicam a abertura dos chuveiros automáticos, o mesmo ocorrendo com o gráfico da pressão.

Tabela 5 - Valores de pressão e temperaturas durante o ensaio de exposição ao fogo em escala real

\begin{tabular}{|c|c|c|c|c|c|}
\hline Tempo (s) & Pressão (kPa) & Sensor $\mathbf{1}$ & Sensor 2 & Sensor 3 & Sensor 4 \\
\hline 0 & 831 & 24,2 & 23,3 & 23,1 & 23,3 \\
\hline 5 & 830 & 24,2 & 23,3 & 23,2 & 23,2 \\
\hline 10 & 827 & 24,7 & 44,4 & 44,1 & 23,6 \\
\hline 15 & 826 & 35 & 111,2 & 113 & 37 \\
\hline 20 & 826 & 49,2 & 228,6 & 227,9 & 56,7 \\
\hline 25 & 835 & 68,1 & 264,3 & 265,2 & 72,8 \\
\hline 30 & 825 & 80,9 & 315,8 & 311,5 & 77,6 \\
\hline 35 & 821 & 100,7 & 274 & 266,7 & 78,3 \\
\hline 40 & 821 & 107,7 & 242 & 234,8 & 83,6 \\
\hline 45 & 819 & 106,2 & 226,5 & 217,5 & 88,1 \\
\hline 50 & 818 & 109,6 & 227,9 & 221,5 & 91,9 \\
\hline 55 & 816 & 109,8 & 228,2 & 221,3 & 91,9 \\
\hline 60 & 820 & 112,8 & 229,2 & 230,1 & 122,3 \\
\hline 65 & 825 & 115,6 & 253,7 & 255,9 & 128,9 \\
\hline 70 & 823 & 115,4 & 269,6 & 269,5 & 143,3 \\
\hline 75 & 640 & 27 & 321,1 & 311,5 & 139,5 \\
\hline 80 & 421 & 36,8 & 311,5 & 299,7 & 35,8 \\
\hline 85 & 406 & 30 & 354,3 & 348,6 & 32,9 \\
\hline 90 & 399 & 28,1 & 346,3 & 340,6 & 33,5 \\
\hline
\end{tabular}

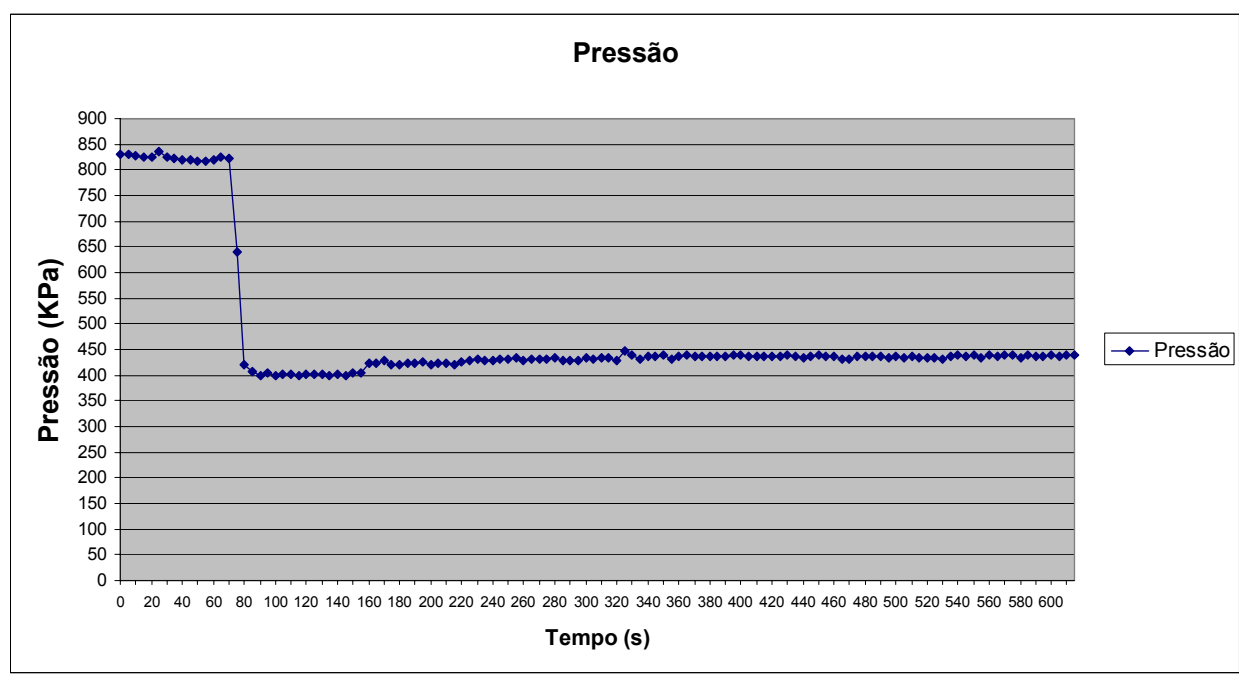

Figura 11 - Gráfico (Pressão x tempo) do ensaio em escala real do corpo-de-prova com o tubo composto vinílico Grau 67 


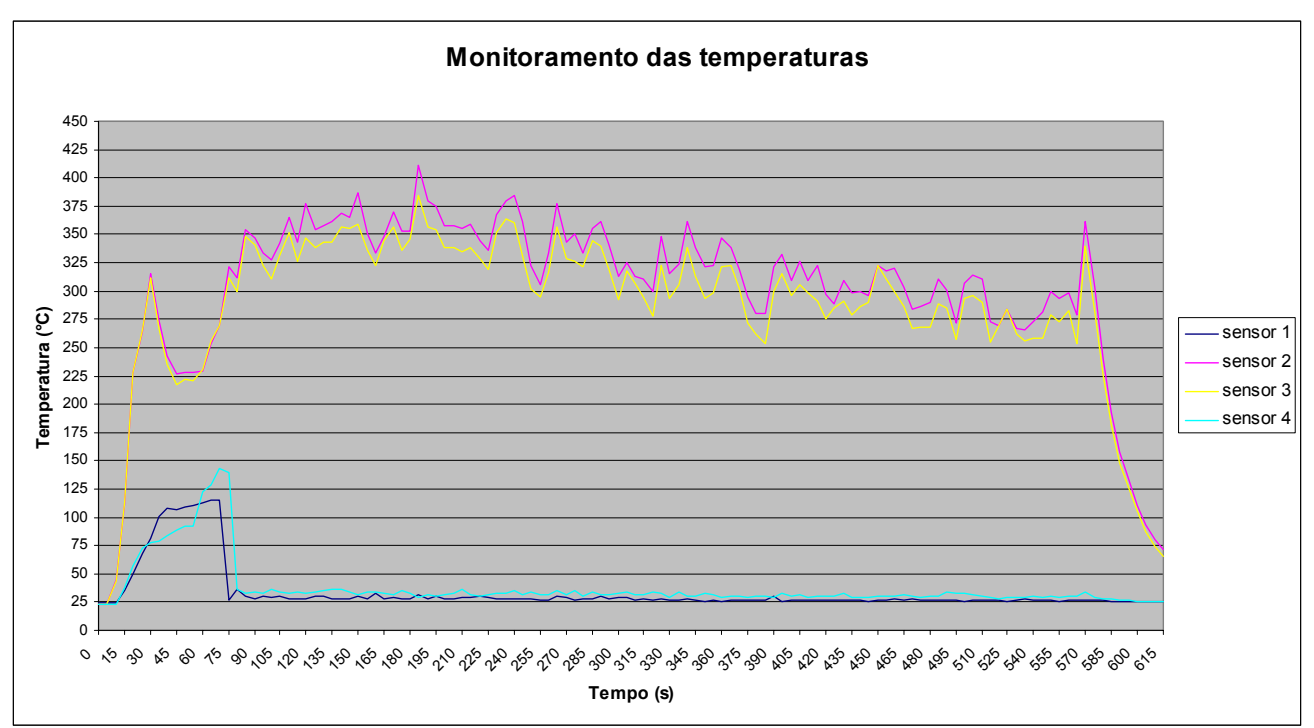

Figura 12 - Gráfico (Temperatura $\mathrm{x}$ tempo) do ensaio em escala real do corpo-de-prova com o tubo composto vinílico Grau 67

\subsection{Avaliação dos resultados obtidos nos ensaios em tubulações em escala real}

Os resultados do ensaio em escala real mostram que as tubulações com percentual acima de 64 suportam as condições de exposição direta às chamas, ou seja, possuem resistência ao fogo às condições estabelecidas no ensaio em escala real. Isto foi verificado na execução do ensaio de exposição direta às chamas e ensaio para verificação de estanqueidade. A Figura 13 apresenta uma foto dos corpos-de-prova com resultado satisfatório, após execução do ensaio de exposição ao fogo.

De todos os ensaios realizados somente o corpo-de-prova com o composto vinílico Grau 57 não suportou as condições estabelecidas no ensaio em escala real. Isto devido ao rompimento do tubo, o qual pode ser visto na Figura 14. Já a Figura 15 apresenta o vazamento ocorrido entre a conexão e o tubo para o segundo ensaio do corpo-de-prova com o tubo composto vinílico grau 64. Este corpo-deprova foi montado posteriormente aos outros, devido ao problema ocorrido no primeiro ensaio, e foi verificado no ato desta montagem que o adesivo estava com aspecto diferente do verificado anteriormente, provavelmente, por ter ficado em ambiente inadequado e pelo frasco do adesivo já ter sido aberto anteriormente. Portanto, a conclusão é que o problema do ensaio foi o processo soldagem entre o tubo e conexão, bem porque no primeiro ensaio para este material não foi verificado qualquer problema de vazamentos. Assim, fica bem claro que o processo qualificado de montagem dos sistemas com este tipo de tubulações é essencial para o seu funcionamento adequado.

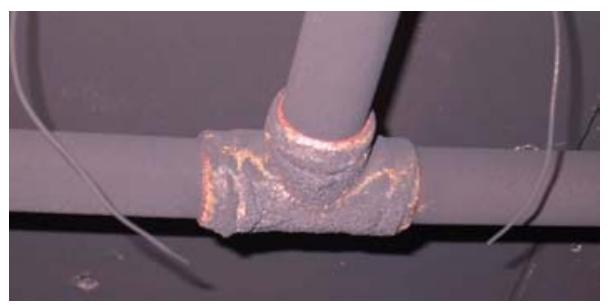

Figura 13: Foto de um corpo-de-prova (região central) após a execução do ensaio exposição ao fogo

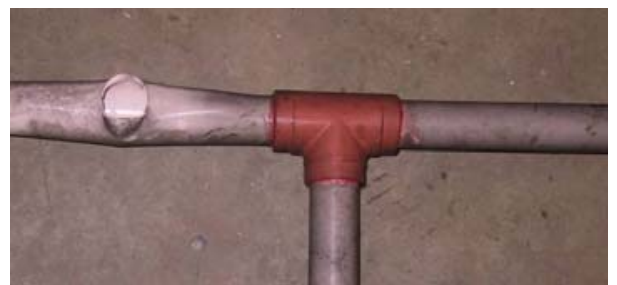

Figura 14: Foto do corpo-de-prova com a ruptura, após a execução do ensaio de exposição ao fogo. 


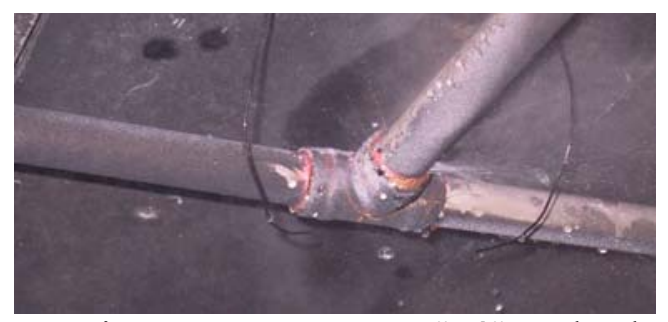

Figura 15: Foto do vazamento na junção entre conexão "Tê" e tubo do corpo-de-prova com o tubo composto vinílico grau 64 (ensaio 2), após execução do ensaio de exposição ao fogo.

\subsection{Avaliação conjunta dos resultados obtidos nos ensaios em trechos de tubulações e nos ensaios em escala real}

A relação entre os resultados indica que para suportar as condições do ensaio em escala real, os materiais devem atingir um tempo mínimo de 110 segundos no ensaio em trechos de tubulações. Em contrapartida, os resultados indicam que materiais com o tempo de ruptura até 55 segundos no ensaio em trechos, não suportam as condições do ensaio em escala real.

A Figura 16 apresenta o gráfico da relação entre os resultados de ambos os ensaios, no qual indica os valores individuais do tempo de ruptura dos corpos-de-prova nos ensaios em trechos de tubulações (pontos vermelhos) em relação ao tipo de material utilizado nos corpos-de-prova, bem como os tempos médios de ruptura (pontos azuis) e a faixa onde há a necessidade de se verificar a resistência ao fogo dos materiais, indicada pela região hachurada do gráfico. Além disso, a Figura 16 indica a região superior à faixa hachurada como os corpos-de-prova que suportam as condições dos ensaios em escala real (incluindo o tempo de 110 segundos) e a região inferior como os corpos-de-prova que não suportam as condições dos ensaios em escala real (incluindo o tempo de 55 segundos).

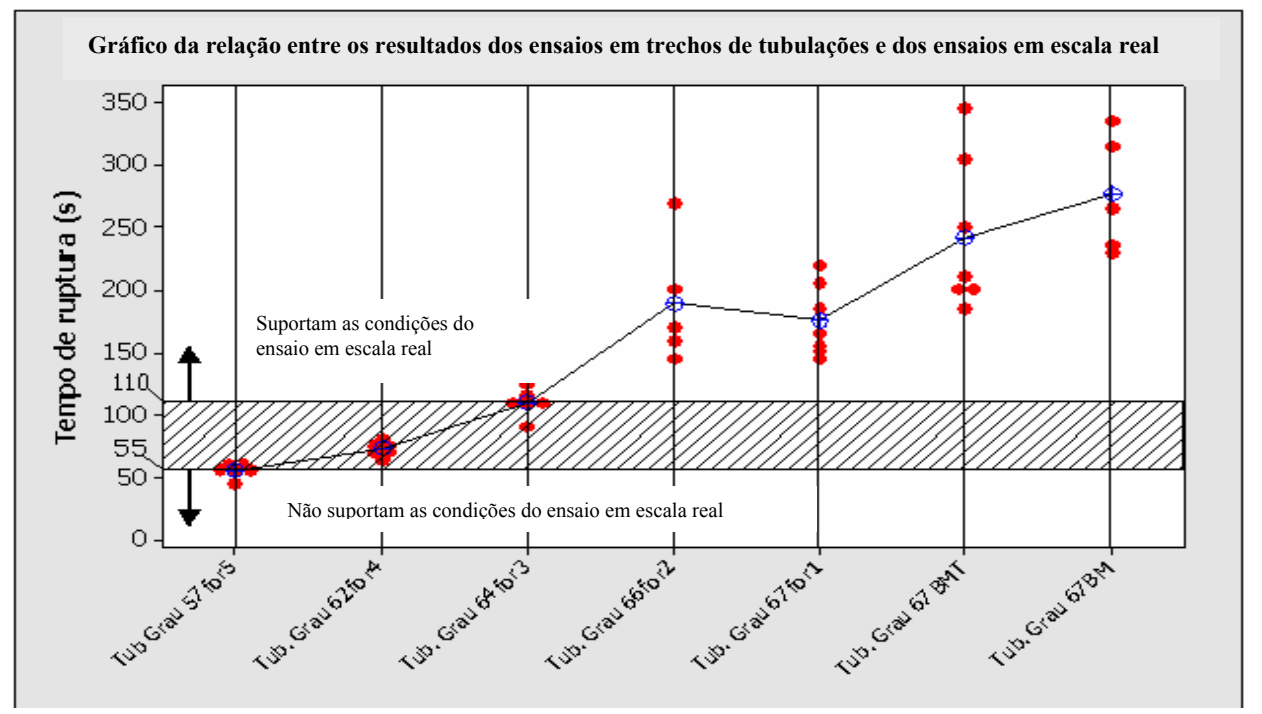

Figura 16: Relação entre os resultados obtidos nos ensaios em trechos de tubulações e nos ensaios em tubulações em escala real

Com base nos resultados apresentados nos ensaios e da relação mostrada acima, conclui-se que os corpos-de-prova com resistência ao fogo a partir de 110 segundos nas condições estabelecidas nos ensaios em trechos de tubulações suportam as condições de exposição ao fogo nos ensaios em escala real. A Tabela 13 apresenta os resultados da relação entre ambos os ensaios, para os corpos-de-prova selecionados, sendo visualizado os tempos de ruptura nos ensaios em trechos de tubulações, relacionados ao atendimento dos critérios estabelecidos nos ensaios em escala real. 
Tabela 6: Avaliação conjunta os resultados dos ensaios em trechos de tubulações e em escala real

\begin{tabular}{|l|c|c|}
\hline \multicolumn{2}{|c|}{ Resultados dos ensaios em trechos de tubulações e em tubulações em escala real } \\
\hline Identificação dos corpos-de-prova & $\begin{array}{c}\text { Ensaios em trechos de tubulações } \\
\text { - Médias do tempo de ruptura } \\
\text { (s) }\end{array}$ & $\begin{array}{c}\text { Ensaios em escala real - Atendeu } \\
\text { aos critérios do ensaio? } \\
\text { (Sim ou Não) }\end{array}$ \\
\hline Com o tubo vinílico grau 57 & 55 & Não \\
\hline Com o tubo vinílico grau 64 & 110 & Sim \\
\hline Com o tubo vinílico grau 67 & 175 & Sim \\
\hline Com o tubo vinílico grau 67 BMT & 242 & Sim \\
\hline
\end{tabular}

Notas:

- Todos os resultados apresentados fazem referência às condições estabelecidas na metodologia desta pesquisa

Portanto, os resultados indicaram a possibilidade de se utilizar os ensaios em trechos de tubulações ou ensaio com corpos-de-prova de pequenas dimensões inseridas em um equipamento de ensaio (forno), para avaliar, preliminarmente, a capacidade dos materiais em resistir ao fogo, antes de serem submetidos ao ensaio em escala real. Tal relação simplifica a avaliação da resistência ao fogo dos materiais utilizados na fabricação de tubulações, pois através do tempo de ruptura obtido nos ensaios em trechos de tubulações podem ser selecionados apenas os materiais que suportam as condições do ensaio em escala real, já que este apresenta maiores custos envolvidos e maiores dificuldades na execução.

\section{CONSIDERAÇÕES FINAIS}

As informações obtidas e apresentadas nesta pesquisa contribuirão para o desenvolvimento, no contexto nacional, de novos materiais empregados nos sistemas de chuveiros automáticos para extinção de incêndios, os quais poderão propiciar novas alternativas de projetos e, consequentemente, propiciar maior proteção das edificações, buscando salvaguardar as vidas humanas e proteger os bens materiais.

A pesquisa resultou em avanços no conhecimento relativo ao tema resistência ao fogo de compostos vinílicos aplicados na fabricação de tubulações para sistemas de chuveiros automáticos. Assim, os ensaios em trechos de tubulações mostraram que quanto maior o teor de cloro nestes compostos maior sua resistência ao fogo (maior tempo de ruptura), ou seja, o composto com menor teor de cloro apresentou tempo de ruptura média de 55 segundos e o composto com maior teor de cloro 276 segundos, lembrando que estes ensaios foram desenvolvidos nesta pesquisa. Já os ensaios em escala real, os quais têm suas características de execução e critérios de avaliação bem definidos em normas, mostraram a capacidade dos materiais resistirem a uma situação real de exposição ao fogo e estes indicaram que a tubulação com composto vínilico grau 57 não suportou as condições do ensaio e as tubulações com os compostos vinílicos grau 57, 67 e 67 BMT suportaram.

Em função dos resultados obtidos nos dois tipos de ensaios, foi possível estabelecer uma relação entre eles. Isto indica a possibilidade de se utilizar os ensaios trechos de tubulações para avaliar, preliminarmente, a capacidade dos materiais em resistir ao fogo, antes de serem submetidos aos ensaios em escala real, o qual apresenta maiores custos envolvidos e maiores dificuldades na sua execução. Assim, os compostos vinílicos para a fabricação de tubulações com tempo de ruptura de, no mínimo, 110 segundos nas condições estabelecidas nos ensaios em trechos de tubulações suportam as condições de exposição ao fogo nos ensaios em tubulações em escala real. 


\section{REFERÊNCIAS BIBLIOGRÁFICAS}

ASSOCIAÇÃO BRASILEIRA DE NORMAS TÉCNICAS - ABNT. Chuveiros Automáticos para extinção de incêndio. NBR 6125. Rio de Janeiro, 12 p. 1992.

ASSOCIAÇÃO BRASILEIRA DE NORMAS TÉCNICAS - ABNT. Proteção contra incêndio por chuveiro automático. NBR 10897. Rio de Janeiro, 76 p. 1990.

BERTO, A. F. Medidas de Proteção contra Incêndio: Aspectos Fundamentais a serem considerados no projeto arquitetônico dos edifícios. 1995. 273p. Dissertação (Mestrado) Faculdade de Arquitetura e Urbanismo da Universidade de São Paulo. São Paulo.

COSTA NETO, P. L. O. Estatística. 2ª Edição. São Paulo: Editora Edgard Blücher, 2002. 266 p.

DALAL, G. T. Chlorinated poly(vinyl chloride) (CPVC) engineering thermoplastic now a viable alternative. Journal of Vinyl and Additive Technology. Vol.7, Issue 1, p.36-41, mar 1985.

GONÇAlVES, O. M.; FEITOSA, E. P. Sistemas de Chuveiros Automáticos. Texto Técnico. São Paulo. 1998. Escola Politécnica da Universidade de São Paulo. São Paulo

MRUK, S. A. Standard Handbook of Plant Engeneering: Chapter 5.14 - Plastics Piping. Digital Engeneering Library @McGraw-Hill. New York, p. 5.283-5.314, 2004.

MRUK, S. A; MCGRATH, T. J. Piping Handbook: Chapter D1 - Thermoplastics Piping. Digital Engeneering Library @McGraw-Hill. Columbus,OH, p. D1-D78, 2004.

NASCIMENTO FILHO, V. F. Técnicas analíticas nucleares de fluorescência de raio $\mathbf{X}$ por dispersão de energia (ED-XRF) e por reflexão total.. Texto Técnico. Piracicaba. 1999. Escola Superior de Agricultura Luiz de Queiroz (ESALQ)

NAM, S.. Fire test to evaluate CPVC pipe sprinkler systems without fire resistance barriers. Fire Safety Journal. Boston, vol. 40, p.595-609, out 2005.

NATIONAL FIRE PROTECTION ASSOCIATION Installation of Sprinklers Systems. NFPA 13. Boston, 311p. 2002.

NUNES, L. R., RODOLFO JUNIOR, A., ORMANJI, W. Tecnologia do PVC. São Paulo: Proeditores / Braskem 2002. 400p.

TOMINA, J. C. Sistemas prediais de chuveiros automáticos de extinção de incêndio: qualidade das tubulações de cpve. 1991. 351p. Dissertação (Mestrado) - Escola Politécnica da Universidade de São Paulo. São Paulo.

UNDERWRITERS LABORATORIES Thermoplastic Sprinkler Pipe and Fittings for Protection Service - UL-1821. New York, 34 p . 2003. 